\title{
Efficacy of Exercise Combined with Music on Pain and Range of Motion in Pediatric Lower Limb Burn
}

\author{
MARWA M. EID, Ph.D.*; ERENY S. WAHBA, Ph.D.* and MOHAMED S. MOHAMED, M.Sc.** \\ The Department of Physical Therapy for Surgery, Faculty of Physical Therapy, Cairo University* and \\ Physical Therapy Department, $6^{\text {th }}$ October Hospital**
}

\begin{abstract}
Background: Music therapy is the use of music to improve health or functional outcomes. Music therapy is a creative arts therapy.
\end{abstract}

Aim of Study: This study was conducted to investigate effect music with exercise on range of motion and pain in pediatric lower limb burn.

Subjects: Thirty patients with 2nd degree lower limb burn were conducted in the present study. All patients with age ranged from 10 to 15 years. They were selected from El-Kasr El-Ainy Hospital and Om El-Masreen Hospital in Cairo, Egypt.

Methods: Patients assigned randomly into two Groups (A and B) equal in number: Group (A) fifteen patients received the traditional physiotherapy plus music with exercise $\mathrm{v}$ for 12 weeks ( 3 sessions/week). Group (B) fifteen patients received the recommended traditional physiotherapy for 12 weeks.

Evaluation: Evaluation of both Groups (A and B) were done before starting the treatment and at the end of study by visual analog scale and goniometer

Results: This study showed a statistically significant improvement in range of motion and pain. Increase in flexion and extension and ankle dorsiflexion and planter flexion in Group A than Group B and significant improvement in pain in Group A than Group B.

Conclusion: Music with exercise is an effective modality for improving range of motion and pain.

Key Words: Burn - Music therapy - Range of motion - Pain.

\section{Introduction}

BURNS are classified into 4 degrees according to depth of injury: In 1 st degree burns are superficial injuries, involving only the outer layers of epithe-

Correspondence to: Dr. Marwa M. Eid, The Department of Physical Therapy for Surgery, Faculty of Physical Therapy, Cairo University lium, 2nd degree in which there is destruction of the epidermal layer, in $3^{\text {rd }}$ degree there is complete epidermal and dermal destruction, in $4^{\text {th }}$ degree burn destroys the underlying tissues, subcutaneous fat, muscles, nerves, and get deeper to bones and joints [2]. In first-degree burn there is effect only the top layer of the epidermis and there is redness without any blistering. As in Sunburn, in seconddegree burn, known as a partial-thickness burn, the deeper layers are affected and results in painful blisters. Superficial second-degree burns often result from scalds. These burns may be very painful, but they generally heal rapidly without scarring. Deeper second-degree burns often result from contact with flames, or with hot oil or grease. In third-degree burns are known as full-thickness burns. They affect the all layers of the skin and also the layer of tissue below the skin (subcutaneous tissue). Third-degree burns often are very pale and cause little pain at first, since all nerve endings have been destroyed. These burns may result from flames, scalds, chemical exposure, or electrical injuries. Individuals will develop significant scars and contractures of those joints involved in the injury. Fourth-degree burns are extremely severe; these burns are third-degree burns that extend deeper into muscle and bone tissue [3]

They are also classified into 3 degrees according to percentage of total body surface area: Minor in which less than $10 \%$ of TBSA is involved, major in which more than $10 \%$ of TBSA is involved, dangerous in which more than $30 \%$ of TBSA is involved [4]

Music therapy is the use of music to improve health or functional outcomes. Music therapy is a creative arts therapy, consisting of a process in which a music therapist uses music and all of its facets-physical, emotional, mental, social, aesthetic, 
and spiritual-to help clients improve their physical and mental health. Music therapists primarily help clients improve their health in several domains, such as cognitive functioning, motor skills, emotional development, communication, sensory, social skills, and quality of life by using both active and receptive music experiences such as improvisation, re-creation, composition, and listening and discussion of music to achieve treatment goals. There is a wide qualitative and quantitative research literature base [5].

Music therapy has multiple benefits which contribute to the maintenance of health and the drive toward rehabilitation for children. Advanced technology that can monitor cortical activity offers a look at how music engages and produces changes in the brain during the perception and production of musical stimuli. Music therapy, when used with other rehabilitation methods, has increased the communicative rehabilitation [9].

Some commonly found practices include developmental work (communication, motor skills, etc.) with individuals with special needs, songwriting and listening in reminiscence/orientation work with the elderly, processing and relaxation work, and rhythmic entrainment for physical rehabilitation in stroke victims. Music therapy is also used in some medical hospitals, cancer centers, schools, alcohol and drug recovery programs, psychiatric hospitals, and correctional facilities [5] .

\section{Subjects and Methods}

This study was started from June 2017 till June 2018 at El-Kasr El-Ainy Hospital and Om ElMasreen Hospital in Cairo, Egypt.

Subjects: Thirty patients who had lower limb burn since 6 months and they were selected from El-Kasr El-Ainy Hospital and Om El-masreen hospital and patients were assigned randomly into two groups of equal numbers, (Group A and Group B).

Inclusive criteria: All patients participated in this study were males and females, age ranged between 10 and 15 years, had lower limb burn since 6 months and have sufficient cognition and education enough to understand the requirements of the study.

Exclusive criteria: The current study was excluded the following patients:

- Age more than 15 years or less than 10 years.

- Subjects with hearing problems.
- Patients with acute viral diseases, acute tuberculosis, mental disorders or those with pace makers.

- Diabetic, cardiac and renal patients.

- Genetic disease.

- 3 rd degree burn and 1 st degree bum.

Equipment: The study equipment were divided into two different categories, measuring and therapeutic equipment.

- Measuring equipment: Goniometer and visual analogue scale.

- Treatment equipment: Cassette as a source of playing music.

Procedure of application: The subjects will be informed about the nature of the study; each subject signed consent form before participating in the study. Treatment time of the present study was given in the period of 12 weeks.

Group A (study group): Patients in study group treated with music with exercise $15 \mathrm{~min}, 3$ times weekly on a platform set to music at $(60 \mathrm{~Hz}$ and intensity $5 \mathrm{~mm}$ ) in additional to traditional physiotherapy 12 weeks.

Group B (control group): Patients in control group receive traditional physiotherapy for 12 weeks.

Ethical consideration: Confidentiality was assured by signing the consent form and respect to all patients was ascertained through explaining the objectives of the study and its benefits. The study was approved by Ethical Committee of Faculty of Physical Therapy, Cairo University (P.T.REC/012/001000).

\section{Statistical analysis:}

Descriptive statistics and unpaired $t$-test were conducted for comparison of subject characteristics between both groups. Chi-squared test was used for comparison of subject characteristics between both groups. Chi-squared test was used for comparison of sex distribution between groups. Normal distribution of data was checked using the ShapiroWilk test. Levene's test for homogeneity of variances was conducted to ensure the homogeneity between groups. Unpaired $t$-test was conducted to compare VAS, ankle and knee ROM between the study and control groups. Paired $t$-test was conducted for comparison between pre and posttreatment in each group. The level of significance for all statistical tests was set at $p<0.05$. All statis- 
tical analysis was conducted through the Statistical Package for Social Studies (SPSS) Version 22 for windows (IBM SPSS, Chicago, IL, USA).

\section{Results}

\section{Subject characteristics:}

Table (1) showed the mean \pm SD age of the study and control groups. There was no significant difference in age between both groups $(p=0.46)$. Also, there was no significant difference in sex distribution between groups $(p=0.4)$.

Effect of treatment on mean symmetry index of step length, stride length, stance time and swing time:

\section{- Within group comparison:}

VAS: There was a significant decrease in VAS post-treatment in the study and control groups compared with that pre-treatment $(p>0.0001)$. The percent of decrease in VAS in the study group was $77.85 \%$ and that in control group was $67.8 \%$.

ROM: There was a significant increase in ankle and knee ROM post-treatment in the study and control groups compared with that pre-treatment $(p>0.0001)$. The percent of increase of ankle dorsiflexion, planter flexion, knee flexion and extension in the study group were $38.57,15.63,5.7$ and $2.5 \%$ respectively; while that in control group were 20.61, 9.89, 2.98 and $1.63 \%$ for ankle dorsi flexion, planter flexion, knee flexion and extension respectively.

\section{- Between groups comparison:}

There was no significant difference in VAS, ankle and knee ROM between both groups pretreatment $(p>0.05)$. Comparison between the study and control groups post-treatment revealed a significant decrease in VAS and a significant increase in ankle and knee ROM of the study group compared with that of the control group $(p>0.01)$.

Table (1): Comparison of subject characteristics between study and control groups.

\begin{tabular}{|c|c|c|c|c|}
\hline & $\begin{array}{l}\text { Study group } \\
\text { Mean } \pm S D\end{array}$ & $\begin{array}{l}\text { Control group } \\
\text { Mean } \pm \mathrm{SD}\end{array}$ & $\begin{array}{c}t- \\
\text { value }\end{array}$ & $\begin{array}{c}p- \\
\text { value }\end{array}$ \\
\hline Age (years) & $12.66 \pm 1.58$ & $13.06 \pm 1.33$ & -0.74 & 0.46 \\
\hline $\begin{array}{l}\text { Sex: } \\
\text { Girls } \\
\text { Boys }\end{array}$ & $\begin{array}{ll}3 & (20 \%) \\
12 & (80 \%)\end{array}$ & $\begin{array}{ll}5 & (33 \%) \\
10 & (67 \%)\end{array}$ & $\begin{array}{l}\left(\chi^{2}=\right. \\
0.68)\end{array}$ & 0.4 \\
\hline
\end{tabular}

Table (2): Mean VAS, ankle and knee ROM pre and posttreatment of the study and control groups.

\begin{tabular}{|c|c|c|c|c|}
\hline & $\begin{array}{l}\text { Study group } \\
\text { Mean } \pm \text { SD }\end{array}$ & $\begin{array}{c}\text { Control group } \\
\text { Mean } \pm \text { SD }\end{array}$ & $\begin{array}{c}t- \\
\text { value }\end{array}$ & $\begin{array}{c}p- \\
\text { value }\end{array}$ \\
\hline $\begin{array}{l}\text { VAS: } \\
\text { - Pre } \\
\text { - Post } \\
\text { - MD } \\
\text { - } \% \text { of change } \\
\text { - } t \text {-value }\end{array}$ & $\begin{array}{l}4.2 \pm 0.86 \\
0.93 \pm 0.25 \\
3.27 \\
77.85 \\
13.16 \\
p=0.0001 *\end{array}$ & $\begin{array}{l}4.13 \pm 0.91 \\
1.33 \pm 0.48 \\
2.8 \\
67.8 \\
12.58 \\
p=0.0001 *\end{array}$ & $\begin{array}{l}0.2 \\
-2.8\end{array}$ & $\begin{array}{l}0.83 \\
0.009 *\end{array}$ \\
\hline $\begin{array}{l}\text { Dorsi flexion } \\
\text { ROM (degrees) } \\
\text { - Pre } \\
\text { - Post } \\
\text { - MD } \\
\text { - } \% \text { of change } \\
\text { - } t \text {-value }\end{array}$ & $\begin{array}{l}13.66 \pm 1.17 \\
18.93 \pm 1.43 \\
-5.27 \\
38.57 \\
-14.7 \\
p=0.0001^{*}\end{array}$ & $\begin{array}{l}14.26 \pm 1.38 \\
17.2 \pm 1.7 \\
-2.94 \\
20.61 \\
-8.87 \\
p=0.0001 *\end{array}$ & $\begin{array}{l}-1.27 \\
3.01\end{array}$ & $\begin{array}{l}0.21 \\
0.005 *\end{array}$ \\
\hline $\begin{array}{l}\text { Planter flexion } \\
\text { ROM (degrees) } \\
\text { - Pre } \\
\text { - Post } \\
\text { - MD } \\
\text { - } \% \text { of change } \\
\text { - } t \text {-value }\end{array}$ & $\begin{array}{l}33.26 \pm 1.8 \\
38.46 \pm 1.06 \\
-5.2 \\
15.63 \\
-12.49 \\
p=0.0001 *\end{array}$ & $\begin{array}{l}33.06 \pm 1.62 \\
36.33 \pm 1.91 \\
-3.27 \\
9.89 \\
-8.8 \\
p=0.0001 *\end{array}$ & $\begin{array}{l}0.32 \\
3.77\end{array}$ & $\begin{array}{l}0.75 \\
0.001 *\end{array}$ \\
\hline $\begin{array}{l}\text { Knee flexion } \\
\text { ROM (degrees) } \\
\text { - Pre } \\
\text { - Post } \\
\text { - } \mathrm{MD} \\
\text { - } \% \text { of change } \\
\text { - } t \text {-value }\end{array}$ & $\begin{array}{l}125.26 \pm 5.06 \\
132.4 \pm 4.12 \\
-7.14 \\
5.7 \\
-7.98 \\
p=0.0001 *\end{array}$ & $\begin{array}{l}124.93 \pm 3.55 \\
128.66 \pm 2.66 \\
-3.73 \\
2.98 \\
-8.07 \\
p=0.0001 *\end{array}$ & $\begin{array}{l}0.2 \\
2.99\end{array}$ & $\begin{array}{l}0.83 \\
0.006 *\end{array}$ \\
\hline $\begin{array}{l}\text { Knee extension } \\
\text { ROM (degrees) } \\
\text { - Pre } \\
\text { - Post } \\
\text { - MD } \\
\text { - } \% \text { of change } \\
\text { - } t \text {-value }\end{array}$ & $\begin{array}{l}131.06 \pm 2.4 \\
134.33 \pm 0.72 \\
-3.27 \\
2.5 \\
-5.26 \\
p=0.0001 *\end{array}$ & $\begin{array}{l}130.6 \pm 1.35 \\
132.73 \pm 1.28 \\
-2.13 \\
1.63 \\
-7.34 \\
p=0.0001 *\end{array}$ & $\begin{array}{l}0.65 \\
4.21\end{array}$ & $\begin{array}{l}0.51 \\
0.0001 *\end{array}$ \\
\hline
\end{tabular}

SD : Standard Deviation. $p$-value: Probability value MD: Mean Difference. $\quad * \quad$ : Significant.

\section{Discussion}

The current study was designed to evaluate the therapeutic efficacy of exercise combined with music using the visual analog scale and goniometer as a method of evaluation was measured at different times:

Music therapy used in child rehabilitation has had a substantial emphasis on sensorimotor development including; balance and position, locomotion, agility, mobility, range of motion, strength, laterality and directionality [6] 
- Music motivate and can be an element of distraction. Rhythmic stimuli have been found to help balance training for those with a brain injury [7]

- Therapeutic results of the music with exercise outcomes in pediatric lower limb burn are summarized as follow:

The results of this study have significant improvement in pain and range of motion in Group A than Group B.

This concept was supported by some previous studies and past literatures that conducted by following authors $[\mathbf{5 , 8 , 1 0 ]}$.

Approved that providing a structured supplemental music and exercise program in conjunction with occupational and physical therapy seems to improve both passive and active ROM to a greater extent than the standard of care alone. Patients received the 12-week program significantly improved ROM in all joints assessed except for one. Patients received standard of care showed a significant improvement in only one of the joints assessed [5].

A total of 17 studies met the inclusion criteria, for a total of 804 patients. A statistically significant difference in pain relief was demonstrated between music and non-music interventions $(\mathrm{SMD}=-1.26$, $95 \%$ CI $[-1.83,-0.68])$, indicating that music intervention has a positive effect on pain alleviation for burn patients. The results indicated that music interventions markedly reduced anxiety in individuals compared to non-music interventions $(\mathrm{SMD}=$ $-1.22,95 \%$ CI $[-1.75,-0.69])$. Correspondingly, heart rate decreases were found after treatments that included music interventions $(\mathrm{SMD}=-0.60$, $95 \%$ CI $[-0.84,-0.36])$.

A positive correlation was found between treatments including music interventions and pain alleviation, anxiety relief, and heart rate reduction in burn patients. However, additional high-quality studies with carefully considered music interventions for burn patients are still needed [8].

In study investigated the effect of music intervention at dressing change time on burn patients on pain and anxiety, patients were randomly assigned into control (standard intervention) and experimental groups (crystal music intervention) for five consecutive days (35 patients in each group) patients pain measurements were collected before, during and after dressing changes and morphine usage was recorded, the study period was October 2014 to September 2015. There was no difference in morphine dosage for both groups.

At the fourth day of music intervention, burn patients pain before, during, and after dressing changes had significantly decreased pain on the fourth day during and after dressing changes had also significantly decreased [10]

\section{Conclusion:}

From the previous results and discussions, it could be concluded that exercises combined with music improves pain and range of motion in pediatric lower limb burn.

\section{References}

1- HERNDON D.: Chapter 4: Prevention of Burn Injuries. Total burn care (4 th Ed.). Edinburgh: Saunders. p. 46. ISBN 978-1-4377-2786-9, 2012.

2- ESSELMAN P.C.: Burn rehabilitation: An overview. Arch. Phys. Med. Rehabil., 88 (12 Suppl 2): S3-6. Review, 2007.

3- DEMLING, ROBERT H. and JONATHAN D. GATES "Chapter 112: Medical Aspects of Trauma and Burn Care". Cecil Medicine. Eds. L. Goldman, et al. 24 ed. Elsevier Saunders, 2011.

4- BAARVAN M.E., ESSINK-BOT M.L., OEN I.M.M.H., DOKTER J., BOXMA H. and BEECK E.F.:'Functional outcome after burns". A review of burns, February, 32: $1-9,2006$.

5- CHRISTINE TUDEN, MICHAEL SERGHIOU, DAVID N. HERNDON and OSCAR E. SUMAN: Effects of a 12week Rehabilitation Program with Music \& Exercise Groups on Range of Motion in Young Children with Severe Burns, 2014.

6- STANLEY P. and RAMSEY D.: Music therapy in physical medicine and rehabilitation. Australian Occupational Therapy Journal, 47 (3), 2012.

7- LaGASSE A.B. and THAUT M.H.: Music and Rehabilition Neurological Approaches. Music, Health, and Wellbeing. pp. 153-63, 2012.

8- JINYI LI, LIANG ZHOU and YUNGUI WANG: The effects of music intervention on burn patients during treatment procedures: A systematic review and metaanalysis of randomized controlled trials, 2017.

9- YURKOVICH and JENNIFER: The Effect of Music Therapy Entrainment on Physiologic Measures of Infants in the Cardiac Intensive Care Unit: Single Case Withdrawal Pilot Study. Journal of Music Therapy, 2018.

10- HSU K.C., CHEN L.F. and HSIEP P.H.: Effect of music intervention on burn patients' pain and anxiety during dressing changes, 2016. 


\section{فاعلية التمرينات مع الموسيقى على الآلم ومعدل الحركة المبرة فى حروق الطرف السفلى للآطفال}

آجريت هذه الدراسة لمعرفة تآثير التمرينات مع الموسيقى على الآطفال الذين يعانون من حرقق في الطرف السفلى حيث شارك في هذه

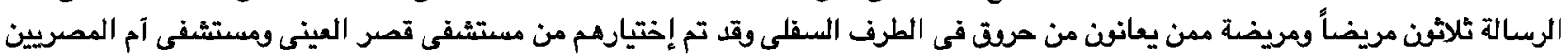

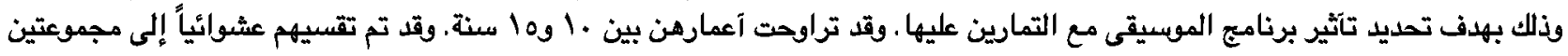

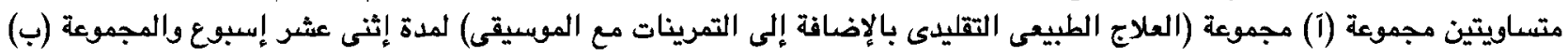

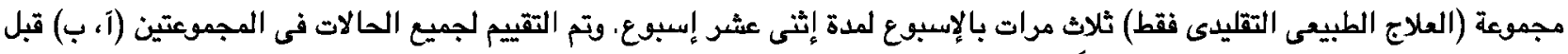

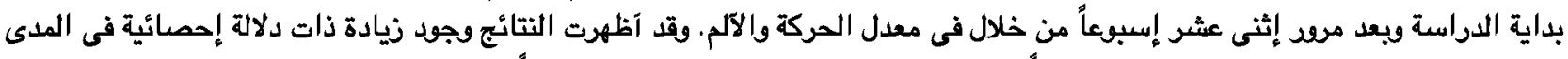

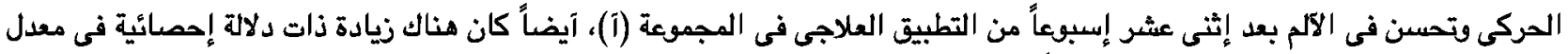

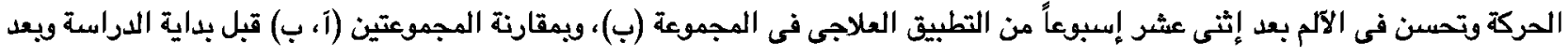

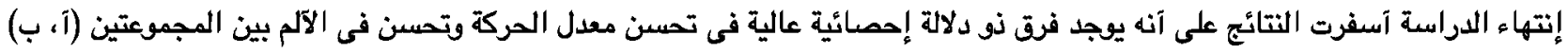

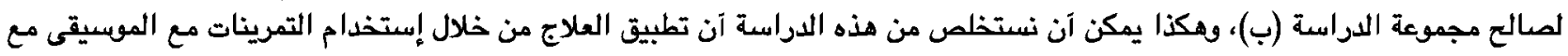

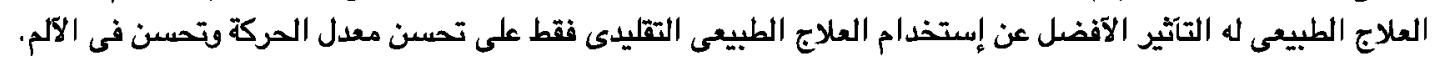

